REVIEW ARTICLE

\title{
胸膜中皮腫に対する集学的治療に向けて
}

\author{
田中文啓 1 橋本昌樹 $1 \cdot$ 多久和輝尚 $1 \cdot$ 松本成司 $1 \cdot$ 近藤展行 $1 \cdot$ \\ 奥村好邦 $1 \cdot$ 村上亜紀 $2 \cdot$ 山田秀哉 $2 \cdot$ 田村邦宣 $2 \cdot$ 飯田慎一郎 $2 \cdot$ \\ 栗林康造 $2 \cdot$ 三宅光富 $2 \cdot$ 福岡和也 $2 \cdot$ 坪田紀明 $3 \cdot$ 上紺屋憲彦 $4 \cdot$ \\ 冨士原将之 $4 \cdot$ 辻村 亨 $5 \cdot$ 長谷川誠紀 $1 \cdot$ 中野孝司 2
}

\section{Perspectives on Multimodality Therapy for Malignant Pleural Mesothelioma}

Fumihiro Tanaka1; Masaki Hashimoto1; Teruhisa Takuwa1; Seiji Matsumoto1; Nobuyuki Kondo1; Yoshitomo Okumura1; Aki Murakami2; Syusai Yamada2; Kunihiro Tamura2; Shinichiro Iida2; Kozo Kuribayashi2; Mitsudomi Miyake2; Kazuya Fukuoka2; Noriaki Tsubota3; Norihiko Kamikonya4; Masayuki Fujiwara4; Tohru Tsujimura5; Seiki Hasegawa1; Takashi Nakano2

${ }^{1}$ Department of Thoracic Surgery, ${ }^{2}$ Division of Respiratory Medicine, Department of Internal Medicine, ${ }^{3}$ Department of Thoracic Oncology, ${ }^{4}$ Department of Radiology, ${ }^{5}$ Department of Pathology, Hyogo College of Medicine, Japan.

ABSTRACT - Objective. The clinical significance of multimodality therapy including surgery for malignant pleural mesothelioma (MPM) has not been established, due to the lack of clinical evidence of its benefit as well as concern regarding its higher toxicity. Method. A total of 19 consecutive patients with MPM, who underwent surgery for curative intent at our institution from April 2004 through November 2007, were retrospectively reviewed. Results. Extrapleural pneumonectomy (EPP) was completed in 16 (84\%) patients, and pathological complete resection was achieved in $14(74 \%)$ patients. In $81 \%$ of patients, preoperative clinical stage was lower than postoperative pathological staging, suggesting that the degree of tumor progression is often underestimated preoperatively. Fatal postoperative complications developed in 2 of 14 patients who underwent EPP, and one patient died of adult respiratory distress syndrome 42 days after EPP. Conclusion. Future clinical trials should be conducted to assess clinical benefit of multimodality therapy, including EPP, for MPM with careful patient selection and proper perioperative care.

(JJLC. 2009;49:392-396)

KEY WORDS — Malignant pleural mesothelioma, Multimodality therapy, Preoperative chemotherapy, Pemetrexed, Extrapleural pneumonectomy

Reprints: Fumihiro Tanaka, Department of Thoracic Surgery, Hyogo College of Medicine, 1-1 Mukogawa, Nishinomiya 663-8501, Japan (e-mail: ftanaka@hyo-med.ac.jp).

要旨一一目的. 悪性胸膜中皮腫に対する手術を含む集 学的治療は, 治療の有効性に関するエビデンスの久如と 毒性に関する懸念から，その臨床的意義が確立していな い. 研究計画. 2004 年 4 月から 2007 年 11 月までの間に 兵庫医科大学病院において治癒目的で悪性胸膜中皮腫に 対する手術を施行された, 連続した 19 症例を後ろ向きに 検討した。結果. 19 例中 16 例 $(84 \%)$ で胸膜肺全摘除術 (EPP) を完遂し，病理学的完全切除は 14 例 $(74 \%)$ に行
いえた. $81 \%$ の症例で術前臨床病期より病理病期が進行 しており, 術前には腫瘍進行度をしばしば過小評価する ことが示唆された。 14 例中 2 例に重篤な合併症が生じ, 1 例は ARDS が原因となって EPP 術後 42 日目に死亡し た. 結論. EPP を含む集学的治療の臨床的有用性を, 厳 格な症例選択と適切な周術期管理の下に, 臨床試験を組 んで検討すべきである.

索引用語 一一 悪性胸膜中皮腫, 集学的治療, 術前化学療
兵庫医科大学 1 呼吸器外科, 2 呼吸器 $\mathrm{RCU}$ 科, 3 胸部腫瘍学, 4 放射 線科, 5病理学・分子病理部門.

別刷請求先：田中文啓, 兵庫医科大学呼吸器外科, $\overline{\mathbf{T}} 663-8501$
西宮市武庫川町 1 番地の 1 (e-mail: ftanaka@hyo-med.ac.jp).

※第 48 回日本肺癌学会総会シンポジウム「悪性中皮腫の克服に 向けて」. 
法, ペメトレキセド, 胸膜肺全摘除術

\section{1.はじめに}

悪性胸膜中皮腫はアスベスト曝露により発生する予後 不良な悪性腫瘍であり，切除可能であってもその術後成 績は極めて不良である. ${ }^{1,2}$ 胸膜中皮腫に対する手術法に は胸膜切除と胸膜肺全摘除術 (extrapleural pneumonectomy, EPP) があるが, 前者は胸膜のみを切除するため に手術侵襲が低い一方で腫瘍遺残の可能性が高く“姑息 的”な手術と位置づけられ，治癒を目指すためには手術 侵襲が大きくても EPPが必要であると考えられるが, そ の術後生存期間中央值は 14 ケ月に過ぎない. ${ }^{3}$ すなわち 切除可能胸膜中皮腫の手術成績を改善するためには手術 に化学療法や放射線治療を加えた集学的治療が必要と認 識され，EPP 後に放射線治療を追加することにより良好 な成績 (Sugarbaker らの 183 例の後ろ向きの検討では全 生存期間中央值は 19 ケ月, 術後 2 および 5 年生存率はそ れぞれ $38 \%$ 抢よび $15 \% 4$; Rusch らの第 II 相試験では $\mathrm{I} \sim \mathrm{II}$ 期症例の全生存期間中央值 33.8 ケ月5) が報告され ている.しかしながら Rusch らの第 II 相試験でも III〜 IV 期の全生存期間中央值は 10 ケ月に過ぎず, 5 また Taverna らの報告でも EPP 後のシスプラチン（以下， CDDP）を含む化学療法と放射線治療の追加では全生存 期間中央值は 13 ケ月に過ぎないと報告 6 しており，悪性 胸膜中皮腫の手術治療成績向上のためには術後のみなら ず術前導入療法 (induction therapy) の必要性が示唆され る.

術前には患側肺が存在しているために，片側全胸郭に 対する放射線治療は肺毒性の点から許容できないため に, 術前導入療法としては化学療法が用いられる. 化学 療法レジメンとしては進行例で従来標準とされていたゲ ムシタビン（以下，GEM）と CDDP の併用療法7,8 が術前 導入療法でも多く用いられ，“術前 GEM/CDDP 併用化 学療法 $\rightarrow \mathrm{EPP} \rightarrow$ 術後片側全胸郭照射”により 良好な予後 がスイス (全生存期間中央值 23 ヶ月，無再発生存期間中 央值 16.5 ヶ月) 9 や米国（EPP 施行症例の全生存期間中 央值 33.5 ケ月) 10 のグループから報告されている. また 最近は新規抗癌剤であるペメトレキセド（以下，MTA） が胸膜中皮腫に対して有効であることが示され，現在で は切除不能症例に対する標準化学療法レジメンは MTA/CDDP 併用療法である11,12 とされ，術前導入療法 においても MTA/CDDP 併用療法が取り入れられつつ ある. ${ }^{33,14}$ しかしながら現時点では, 切除可能胸膜中皮 腫に対する集学的治療，特に新規抗癌郕である MTA を
用いた化学療法を含む集学的治療の安全性・治療コンプ ライアンスや有効性については未だ不明であり，その臨 床的有用性は確立していない. そこで切除可能胸膜中皮 腫に対する集学的治療の問題点や将来展望を明らかにす ることを目的として, 当施設での最近の経験を後ろ向き に検討を行った。

\section{2. 方 法}

兵庫医科大学病院で呼吸器外科が開設された 2004 年 4 月から 2007 年 11 月までの間に, 呼吸器外科で悪性胸 膜中皮腫に対して EPPを試みた症例を後ろ向きに検討 した. 当施設では原則として, 臨床病期 I III 期の症例を $\mathrm{EPP}$ の対象とし，術前にCDDPを用いた併用化学療法 (MTA が認可された 2007 年 1 月以前は $\mathrm{CDDP}+\mathrm{GEM}$, 以降は CDDP+MTA)を行った上で, EPPを施行してい る（化学療法で進行 [progressive disease, 以下 PD] の 症例は手術対象から除外). 術前には換気血流シンチグラ フィー（術後予測残存一秒量 $\geqq 1 l$ ) などにより EPP 耐術 能を評価するとともに, 腫瘍進行度の評価のために $\mathrm{PET} / \mathrm{CT}$ の他に縦隔鏡・対側胸腔鏡および腹腔鏡検查 を行い，縦隔リンパ節転移や対側胸腔および腹腔への進 展などが認められた場合には手術適応から除外した。ま た完全切除例に対する術後の補助放射線治療（片側全胸 郭照射)は，2007 年 10 月ょり開始した。なお，腫瘍進行 度の評価は International Mesothelioma Interest Group （IMIG）による病期分類を用いた.

\section{3. 結 果}

\section{3-1. 症例の背景と治療内容}

EPP を試みた症例は 19 例（性別は男性 14 例と女性 3 例で, 年齢中央值は 62 歳) で, 1 例を除き全例が上皮型 であった．臨床病期は II 期が 68\%（13 例）を占め，III 期症例も 2 例（11\%）含まれていたがいずれも T3NOM0 症例であった（Table 1).

術前化学療法は 17 例 $(89 \%)$ の症例に行われ，化学療 法の内容は 1 例を除いて全例 CDDP を含む併用化学療 法（CDDP + MTA が 8 例, CDDP + CPT-11 + DXR が 7 例，その他 1 例) が行われていた。 $\mathrm{EPP}$ が試みられた 19 例のうち 3 例は完全切除困難（理由は, 広範囲リンパ節 転移, 大動脈浸潤, および多発広範囲胸壁浸潤, 各 1 例) と判断し，試験開胸に終わった。なお，術前に臨床病期 III 期と診断されていた 2 例はいずれも試験開胸に終 わった，EPPを完遂しえた 16 例はいずれも肉眼的には 
Table 1. Patient Characteristics

\begin{tabular}{llc}
\hline & Characteristics & Number of patients (\%) \\
\hline Gender & Male & $14(74 \%)$ \\
& Female & $5(26 \%)$ \\
\hline Age, median & & 62 years (49-71 years) \\
\hline Histology & Epithelioid & $18(95 \%)$ \\
& Biphasic & $1(5 \%)$ \\
\hline Clinical stage & I & $4(21 \%)$ \\
& II & $13(68 \%)$ \\
& III & $2(11 \%)$ \\
\hline
\end{tabular}

Preoperative chemotherapy

\begin{tabular}{|c|c|c|}
\hline & & \\
\hline & CDDP-based chemotherapy & $16(84 \%)$ \\
\hline & $\mathrm{CDDP}+\mathrm{GPT}-11+\mathrm{DXR}$ & 7 (37\%) \\
\hline & $\mathrm{CDDP}+\mathrm{MTA}$ & $8(42 \%)$ \\
\hline & Other CDDP-based & $1(5 \%)$ \\
\hline & Other chemotherapy & $1(5 \%)$ \\
\hline & No chemotherapy & $2(11 \%)$ \\
\hline Mode of operation & EPP completed & $16(84 \%)$ \\
\hline & Complete resection (pathological) & $14(74 \%)$ \\
\hline & Incomplete resection & $2(11 \%)$ \\
\hline & Exploratory thoracotomy & $3(16 \%)$ \\
\hline
\end{tabular}

CDDP, cisplatin; CPT-11, irinotecan; DXR, doxorubicin; MTA, pemetrexed; EPP, extrapleural pneumonectomy.

Table 2. Patients Who Underwent CDDP/MTA Chemotherapy Prior to Surgery

\begin{tabular}{|c|c|c|c|c|c|c|}
\hline & \multicolumn{3}{|c|}{$\begin{array}{l}\text { Preoperative chemotherapy } \\
\text { Doses }\left(\mathrm{mg} / \mathrm{m}^{2}\right) \text { and cycles }\end{array}$} & \multicolumn{2}{|l|}{ Operation } & \multirow{2}{*}{$\begin{array}{c}\text { Postoperative } \\
\text { hemithoracic radiation }\end{array}$} \\
\hline & CDDP & MTA & Cycles & Mode & Complication & \\
\hline 1 & 75 & 500 & 6 & Exploratory thoracotomy & No & Not performed \\
\hline 2 & 75 & 500 & 4 & EPP completed & ARDS (death) & Not performed \\
\hline 3 & 75 & 500 & 3 & EPP completed & $\mathrm{BPF}$ & Completed \\
\hline 4 & 75 & 500 & 3 & EPP completed & No & Completed \\
\hline 5 & 60 & 500 & 3 & EPP completed & No & Completed \\
\hline 6 & 60 & 500 & 3 & EPP completed & No & Not performed \\
\hline 7 & 60 & 500 & 3 & EPP completed & No & Completed \\
\hline 8 & 45 & 375 & 3 & EPP completed & No & Not performed \\
\hline
\end{tabular}

CDDP, cisplatin; MTA, pemetrexed; EPP, extrapleural pneumonectomy; ARDS, adult respiratory distress syndrome; BPF, bronchopleural fistula.

完全切除が行われていたが, このうち 2 例では病理学的 に切除断端に腫瘍細胞浸潤を認めた. 従って最終的に 14 例が病理学的な完全切除と診断された.

$\mathrm{EPP}$ 後の重篤な合併症は 2 例 $(13 \%)$ に生じ，いずれ も CDDP + MTA を用いた術前化学療法施行症例であっ た. 1 例は術後第 15 病日に生じた気管支断端瘦であり同 日緊急手術を行い救命しえたが, 他の 1 例は術後に生じ た成人呼吸促迫症候群（adult respiratory distress syndrome [ARDS]）により術後第 42 病日に死亡した. CDDP + MTA を用いた術前化学療法施行例 8 例を Ta- ble 2 に示すが, 術前化学療法でも非切除例と同様の 75 $\mathrm{mg} / \mathrm{m}^{2}$ の CDDPをMTA $\left(500 \mathrm{mg} / \mathrm{m}^{2}\right)$ に併用した最初 の 4 例では 2 例に $\mathrm{EPP}$ 後に重篤な合併症を認めた. そこ で現在ではCDDP の用量を $60 \mathrm{mg} / \mathrm{m}^{2}$ に減じて術前化 学療法を行っているが, CDDP の用量を減じた 4 例のい ずれにも重篤な合併症を認めていない。また，試験開胸 例 1 例と重篤な合併症を認めた 2 例 (1 例は在院死)を除 いては術後の片側全胸郭照射を施行（または子定）中で ある。 
Table 3. Correlation Between Preoperative Clinical Staging and Postoperative Pathological Staging in Patients Who Underwent Extrapleural Pneumonectomy (EPP) for Malignant Pleural Mesothelioma (MPM)

\begin{tabular}{|c|c|c|c|c|c|}
\hline & & \multicolumn{4}{|c|}{ Postoperative pathological stage } \\
\hline & & $\begin{array}{c}\mathrm{I} \\
(\mathrm{N}=0)\end{array}$ & $\begin{array}{c}\text { II } \\
(\mathrm{N}=3)\end{array}$ & $\begin{array}{c}\text { III } \\
(\mathrm{N}=11)\end{array}$ & $\begin{array}{c}\mathrm{IV} \\
(\mathrm{N}=2)\end{array}$ \\
\hline \multirow{2}{*}{$\begin{array}{l}\text { Preoperative } \\
\text { clinical stage }\end{array}$} & $\begin{array}{c}\mathrm{I} \\
(\mathrm{N}=4)\end{array}$ & & & $\mathrm{N}=3$ & $\mathrm{~N}=1$ \\
\hline & $\stackrel{\Perp 1}{(\mathrm{~N}=12)}$ & & $\mathrm{N}=3$ & $\mathrm{~N}=8$ & $\mathrm{~N}=1$ \\
\hline
\end{tabular}

\section{3-2. 臨床病期と病理病期}

EPP を完遂しえた 16 例について術前臨床病期と病理 病期の比較を Table 3 に示す。術前の臨床病期よりも病 理病期の方が軽かった症例は皆無であり，16 例中 13 例 (81\%)で臨床病期よりも病理病期が進行しており，術前 評価は多くの場合真の腫瘍進展度を過小評価することが 示された。過小評価の内訳を見てみると， 12 例では T 因子が過小評価されており 7 例で術前予測されていな かった縦隔脂肪組織浸潤が認められた。また縦隔りンパ 節転移の評価も術前には困難であり，16 例全例で術前縦 隔リンパ節転移なしと評価したにもかかわらず，病理学 的には 5 例で縦隔リンパ節転移が認められた.

\section{4. 考 察}

今回の切除可能胸膜中皮腫に対する手術を含む集学的 治療に関する検討において，1）EPPを試みた臨床病期 I II 期 19 例中, 16 例 $(84 \%)$ で $\mathrm{EPP}$ を完遂し，病理学 的完全切除は 14 例（74\%）に行いえたこと，2）術前評 価 $(\mathrm{PET} /$ 縦隔鏡含む) は腫瘍進行度を過小評価 $(81 \%$ の 症例で術前臨床病期より病理病期が進行）され，3）術前 化療施行後 EPP 完遂例は 14 例中 2 例に重篤な合併症 （ARDS/気管支断端瘦各 1 例）が生じ，4）全体の治療関 連死亡率は $11 \%(2 / 19)$ で，EPP を含む集学的治療には 厳格な症例選択と細心の注意を要することが示された.

そもそも切除可能胸膜中皮腫に対して手術を行うべき か否かに関しても議論が分かれており，現時点では技術 的に完全切除可能と考えられる胸膜中皮腫症例に手術を 行った方が良いとの信頼性の高いエビデンスは存在せ ず，手術は“標準療法”として臨床実地で推奨されるも のではない. 13 また術式の選択に関しても根治を目指す ための “標準的”術式は EPPであるとされている13が, $\mathrm{EPP}$ は単なる肺全摘除術とは比較にならない大きな侵 襲を伴う術式であり，適切な症例選択や手術および周術 期管理の向上などにより手術の危険性は改善されたもの の，最近の報告でも手術関連死亡は $5 \%$ 程度と依然とし
て高い. 13 ましてや EPP に化学療法や放射線治療を加 える集学的治療は治療成績向上のために必要であって も，その侵襲は非常に大きい。従ってこのような集学的 治療は臨床試験の範囲内で “実験的医療”として行うべ きものであると考えられる。

\section{最後に}

切除可能悪性胸膜中皮腫に対する集学的治療の確立を 目指して, 文部科学省科学技術振興調整費 “アスベスト 関連疾患への総括的取り組み”の一環として，全国規模 の臨床試験が行われることになった. まずCDDP+ $\mathrm{MTA} \rightarrow \mathrm{EPP} \rightarrow$ 片側全胸郭照射（hemithoracic radiation [H-RT]）からなる集学的治療の feasibility を検証する目 的で前向き臨床試験 ( “切除可能悪性胸膜中皮腫に対する ペメトレキセドを含む集学的治療に関する妥当性試験 feasibility study”)が開始された．現時点では悪性胸膜中 皮腫に対する $\mathrm{EPP}$ EPP を含む集学的治療も，臨床的 有用性の確立していない“実験的”治療であり, このよ うな臨床試験を通じて安全性や効果を検証することによ り，新たな治療法の確立を目指すべきであると考えられ る.

本研究は, 文部科学省科学技術振興調整費“アスベスト関連 疾患への総括的取り組み”による補助のもとに行われた

\section{REFERENCES}

1. Flores RM. Induction chemotherapy, extrapleural pneumonectomy, and radiotherapy in the treatment of malignant pleural mesothelioma: the Memorial SloanKettering experience. Lung Cancer. 2005;49(Suppl 1):S7174.

2. Law MR, Gregor A, Hodson ME, Bloom HJ, Turner-Warwick M. Malignant mesothelioma of the pleura: a study of 52 treated and 64 untreated patients. Thorax. 1984;39:255-259.

3. Rusch VW, Piantadosi S, Holmes EC. The role of extrapleural pneumonectomy in malignant pleural mesothelioma. A Lung Cancer Study Group trial. J Thorac Cardiovasc Surg. 1991;102:1-9.

4. Sugarbaker DJ, Flores RM, Jaklitsch MT, Richards WG, Strauss GM, Corson JM, et al. Resection margins, extrapleural nodal status, and cell type determine postoperative long-term survival in trimodality therapy of malignant pleural mesothelioma: results in 183 patients. $J$ Thorac Cardiovasc Surg. 1999;117:54-65.

5. Rusch VW, Rosenzweig K, Venkatraman E, Leon L, Raben A, Harrison L, et al. A phase II trial of surgical resection and adjuvant high-dose hemithoracic radiation for malignant pleural mesothelioma. J Thorac Cardiovasc Surg. 2001;122:788-795.

6. Taverna C, Stahel R, Bodis S, Russi EW, Weder W. Malignant pleural mesothelioma: trimodality therapy in a 
single center. Ann Oncol. 2000;11(Suppl 4):123.

7. Byrne MJ, Davidson JA, Musk AW, Dewar J, van Hazel G, Buck M, et al. Cisplatin and gemcitabine treatment for malignant mesothelioma: a phase II study. J Clin Oncol. 1999;17:25-30.

8. van Haarst JM, Baas P, Manegold Ch, Schouwink JH, Burgers JA, de Bruin HG, et al. Multicentre phase II study of gemcitabine and cisplatin in malignant pleural mesothelioma. Br J Cancer. 2002;86:342-345.

9. Weder W, Kestenholz P, Taverna C, Bodis S, Lardinois D, Jerman M, et al. Neoadjuvant chemotherapy followed by extrapleural pneumonectomy in malignant pleural mesothelioma. J Clin Oncol. 2004;22:3451-3457.

10. Flores RM, Krug LM, Rosenzweig KE, Venkatraman E, Vincent A, Heelan R, et al. Induction chemotherapy, extrapleural pneumonectomy, and postoperative high-dose radiotherapy for locally advanced malignant pleural mesothelioma: a phase II trial. J Thorac Oncol. 2006;1:289-
295.

11. Vogelzang NJ, Rusthoven JJ, Symanowski J, Denham C, Kaukel E, Ruffie P, et al. Phase III study of pemetrexed in combination with cisplatin versus cisplatin alone in patients with malignant pleural mesothelioma. J Clin Oncol. 2003;21:2636-2644.

12. Rusch VW. Pemetrexed and cisplatin for malignant pleural mesothelioma: a new standard of care? J Clin Oncol. 2003;21:2629-2630.

13. 田中文啓, 奥村好邦, 長谷川誠紀, 福岡和也, 中野孝司. 悪性胸膜中皮腫の治療. モダンフィジシャン。2008;28: 912-923

14. Krug LM, Pass H, Rush VW, Kindler HL, Sugarbaker D, Rosenzweig K, et al. A multicenter U.S. trial of neoadjuvant pemetrexed plus cisplatin (PC) followed by extrapleural pneumonectomy (EPP) and hemithoracic radiation (RT) for stage I-III malignant pleural mesothelioma (MPM). Proc ASCO. 2007;25:18s(abstract \# 7561). 